\title{
Egg white versus Salmonella Enteritidis! A harsh medium meets a resilient pathogen
}

Article

Accepted Version

Creative Commons: Attribution-Noncommercial-No Derivative Works 4.0

Baron, F., Nau, F., Guérin-Dubiard, C., Bonnassie, S., Gautier, M., Andrews, S. C. and Jan, S. (2016) Egg white versus Salmonella Enteritidis! A harsh medium meets a resilient pathogen. Food Microbiology, 53 (B). pp. 82-93. ISSN 07400020 doi: https://doi.org/10.1016/j.fm.2015.09.009 Available at https://centaur.reading.ac.uk/70159/

It is advisable to refer to the publisher's version if you intend to cite from the work. See Guidance on citing.

Published version at: http://dx.doi.org/10.1016/j.fm.2015.09.009

To link to this article DOI: http://dx.doi.org/10.1016/j.fm.2015.09.009

Publisher: Elsevier

All outputs in CentAUR are protected by Intellectual Property Rights law, including copyright law. Copyright and IPR is retained by the creators or other copyright holders. Terms and conditions for use of this material are defined in the End User Agreement.

\section{www.reading.ac.uk/centaur}

\section{CentAUR}

Central Archive at the University of Reading 
Reading's research outputs online 


\section{Egg white versus Salmonella Enteritidis!}

\section{A harsh medium meets a resilient pathogen}

Florence Baron*1, $^{1,}$, Françoise Nau ${ }^{1,2}$, Catherine Guérin-Dubiard ${ }^{1,2}$, Michel Gautier ${ }^{1,2}$, Simon Andrews ${ }^{3}$ and Sophie Jan ${ }^{1,2}$

1- Agrocampus Ouest, UMR1253 Science et Technologie du Lait et de l'Euf, F-35042 Rennes, France

2- INRA, UMR1253 Science et Technologie du Lait et de l'Euf, F-35042 Rennes, France

3- School of Biological Sciences, Knight Building, University of Reading, Reading RG6 6AJ, UK

Key words : Egg white, antimicrobial activities, Salmonella Enteritidis, lysozyme, ovotransferrin

Abbreviated running title: Egg white versus $S$. Enteritidis

* Corresponding author. AGROCAMPUS OUEST, INRA, UMR1253, Science et Technologie du Lait et de l'EEuf, F-35000 Rennes, France. Tel.: 33 (0)2 2348 56 94; fax: 33 (0)2 23485861

E-mail address: florence.baron@agrocampus-ouest.fr (Florence Baron) 


\begin{abstract}
Salmonella enterica serovar Enteritidis is the prevalent egg-product-related food- borne pathogen. The egg-contamination capacity of $S$. Enteritidis is largely explained by its exceptional survival capability within the harsh conditions provided by egg white. Egg-white proteins, such as lysozyme and ovotransferrin, are well known to play important roles in defence against bacterial invaders. Indeed, several additional minor proteins and peptides have recently been found to play known or potential roles in protection against bacterial contamination. However, although such antibacterial proteins are well studied, little is known about their efficacy under the environmental conditions prevalent in egg white. Thus, the influence of factors such as temperature, alkalinity, nutrient restriction, viscosity and cooperative interactions on the activities of antibacterial proteins in egg white remains unclear. This review critically assesses the available evidence on the antimicrobial components of egg-white. In addition, mechanisms employed by $S$. Enteritidis to resist egg white exposure are also considered along with various genetic studies that have shed light upon egg-white resistance systems. We also consider how multiple, antibacterial proteins operate in association with specific environmental factors within egg white to generate a lethal protective cocktail that preserves sterility.
\end{abstract}




\section{Introduction}

The avian egg white is an intracellular fluid that functions to protect the developing embryo against invading bacteria. In contrast to the immune system of animals which produces antibodies when needed, the avian egg white can efficiently resist microorganisms over a prolonged period in the absence of any inducible innate or adaptive host defence. Many studies have demonstrated that egg white is a poor medium for bacterial growth due to its harsh physicochemical conditions (alkaline $\mathrm{pH}$, high viscosity, nutritional deficiencies), but also because it contains an arsenal of antimicrobial molecules (Alabdeh et al., 2011 ; Baron et al., 1997 ; Clavijo et al., 2006 ; Garibaldi 1960 ; Kang et al., 2006 ; Lu et al., 2003).

Under healthy breeding conditions, the egg contents, including egg white, is generally sterile just after laying. However, the egg can be infected by external sources due to contamination of the eggshell surface and subsequent penetration of microorganisms into the egg. Eggs are particularly prone to such infection after laying. The eggshell may be exposed to microorganisms from hen faeces, other microorganisms present in the farm environment or downstream, in the environment of the conditioning centres. Cracks in the eggshell increase the risk of internal penetration of contamination. In the case of Salmonella, eggs may be also contaminated during their formation in the ovary or in the oviduct of infected hens (vertical contamination). However, this type of contamination is sporadic. Indeed, the number of contaminated eggs produced by infected flocks is very limited, as is the number of Salmonella cells found within eggs, provided that eggs are fresh (Efsa, 2014). Exogenic bacterial contamination of eggs is, therefore, far more frequent than vertical contamination overall.

The risk of contamination by Salmonella is a real threat for human health and remains a major concern for egg production and processing. In particular, contamination by Salmonella enterica serovar Enteritidis is widely studied because it represents the predominant serotype involved in the foodborne diseases (salmonellosis) due to egg or egg product consumption 
(EFSA 2014). It is also notable that $S$. Enteritidis is able to survive in egg white in contrast to other similar strains and species (Clavijo et al., 2006 ; Gantois et al., 2008 ; Guan et al., 2006 ; Lock and Board 1992). For these reasons, this bacterium is the target in many studies on the antimicrobial activity of egg white.

The aim of this review is to provide a comprehensive overview of the antimicrobial activities of egg white against Gram-negative bacteria, especially Salmonella Enteritidis, under the specific physicochemical conditions encountered in egg white. A few studies involving Grampositive bacteria are also included in cases that provide additional insight concerning the antibacterial mechanisms of egg white against $S$. Enteritidis. The antibacterial proteins of egg white and their mechanism of action are described along with a consideration of their likely roles, and potential synergistic behaviours, under conditions that correspond to those found within the complex medium of the egg white This review also considers how $S$. Enteritidis is able resist the defences of egg white and evaluates the evidence provided by genetic studies on the various mechanisms of egg-white resistance. In this way, we intend to provide insight into the manner in which $S$. Enteritidis attempts to thwart the multifactorial defensive ploys imposed by egg white.

\section{Egg white composition: general data}

Egg white is a heterogeneous medium consisting of four physically separate layers (Dubiard Guérin et al., 2010):

(i) the chalaze layer which corresponds to spiral filaments ranging from the egg yolk to the two ends of the egg. They allow maintenance of egg yolk in suspension in a central position;

(ii) the external liquid egg white which is in direct contact with the shell membranes;

(iii) the thick egg white which is fixed to the ends of the egg and has the appearance of a gel; and 
(iv) the internal liquid egg white which is located between thick egg white and egg yolk.

The proportions of liquid and thick egg whites depend on many factors such as the weight of the egg, the laying rate, the strain, the age and health status of the hen, and especially the duration and method of egg storage (Sauveur, 1988). Egg white is globally an aqueous solution of proteins $(10.6 \%)$ containing small amounts of carbohydrates $(0.9 \%)$ and minerals $(0.5 \%)$. Some of the proteins are present in large quantities, such as ovalbumin which represents more than $50 \%$ of total proteins; others are found in trace amounts (see Guérin-Dubiard et al., 2010 for a review). Fifty percent of carbohydrates are represented by free glucose. Other sugars are incorporated into the polysaccharide moieties of the egg-white glycoproteins. The monomeric units are galactose, mannose, glucosamine, galactosamine and sialic acids.

The main egg white minerals are chloride, sodium, sulfur and potassium (Table 1). Whereas chloride, sodium and potassium are mainly free in solution, sulfur is a constituent element of egg white proteins. Calcium and magnesium are present at equivalent levels, they are partly bound to proteins and are heterogeneously distributed between thick and thin egg white (Sauveur, 1988). Iron is present in small amounts, but considering the ovotransferrin concentration in egg white (about $1.7 \mathrm{mmol} . \mathrm{L}^{-1}$ ), and the strong affinity of this protein for iron and its ability to chelate two iron atoms per molecule, it can be considered that all the iron present in egg white is bound to ovotransferrin.

Due to its aqueous nature, the egg white is devoid of fat-soluble vitamins (A, D, E and Kvitamins). However, it contains all the B-vitamins (Table 2) (Nys and Sauveur, 2004), including: thiamine (vitamin B1) which is the precursor of thiamine pyrophosphate, a prosthetic group of several enzymes involved in decarboxylation and transketolation reactions; riboflavin (vitamin B2), which is the precursor of the prosthetic groups of flavoproteins, flavin adenine dinucleotide (FAD) and flavin mononucleotide (FMN); and 
biotin (vitamin B8), which is a prosthetic group of enzymes involved in carboxylation reactions, including pyruvate and acetyl-CoA carboxylations.

\section{Antimicrobial egg white proteins and peptides}

Several proteins, such as lysozyme, ovotransferrin and proteinase inhibitors, have all been commonly suggested to explain the ability of egg white to prevent bacterial growth. These molecules are naturally abundant in egg white, but it is noteworthy that some minor proteins and peptides recently revealed by high throughput approaches might also play a role in the defence against bacterial contamination. Table 3 presents the major proteins, as well as the minor proteins and peptides, found in egg white that exhibit confirmed or predicted antimicrobial activities in their native state.

\subsection{Lysozyme}

Lysozyme is a ubiquitous protein, present in many biological fluids and tissues of a large number of living organisms. Hen egg white has a particularly high lysozyme content (around 3.5 g. $\left.\mathrm{L}^{-1}\right)$. Lysozyme is an alkaline protein ( $\mathrm{pI}$ of 10.7$)$ of $14.3 \mathrm{kDa}$ (129 amino acid residues). It is an important component of the non-specific defense mechanisms due to its ability to control the growth of susceptible bacteria, and the bactericidal activity exhibited is reported to involve several mechanisms.

The best known activity of lysozyme is the degradation of the glycosidic (1-4) B-linkage between the $\mathrm{N}$-acetylglucosamine and the $\mathrm{N}$-acetylmuramic acid residues of the bacterial peptidoglycan of Gram-positive bacteria. The peptidoglycan forms a strong, woven mesh that allows solutes to pass through, while maintaining the cell's shape and protecting the cell from osmotic lysis. Without this wall, or when it is attacked by lysozyme, the cell would swell and burst. However, cell death due to the lytic action of lysozyme on peptidoglycan occurs only in 
low osmotic strength media, or when the rate of the synthesis and polymerization process for new peptidoglycan formation is slower than the degradation by lysozyme. Gram-negative bacteria are generally resistant to the lytic action of lysozyme, because of the protection provided by the outer-membrane that functions as a permeability barrier preventing the entrance into the cell of molecules larger than $650 \mathrm{Da}$ (Nikaido 2003).

Strikingly, some Enterobacteriaceae express lysozyme inhibitors in the periplasm, suggesting that disturbances of the outer membrane are possible under natural conditions. Moreover, in vitro experiments have shown that these lysozyme inhibitors actually protect bacteria against lysozyme when the outer membrane is permeated by bivalent cations able to chelate charged molecules (Callewaert et al. 2008; Deckers et al 2004). Callewaert et al. (2008) identified a periplasmic lysozyme inhibitor ( $p l i C$ ) of c-type lysozyme in Salmonella Enteritidis. These authors showed that a pliC knock-out mutant was more susceptible to the antimicrobial activity of lysozyme compared to the wild type strain. They also observed increasing sensitivity of this mutant to lysozyme in the presence of lactoferrin, a protein able to permeabilize the outer membrane. Considering the widespread occurrence and effectiveness of lysozyme as a component of innate immunity in animals, it is not surprising that pathogenic bacteria have developed mechanisms of resistance to hydrolysis by lysozyme.

A second non-specific and non-hydrolytic mechanism of lysozyme activity against Gramnegative bacteria involves membrane disruption (Masschalck et al, 2003; Pellegrini et al, 1992; Pellegrini et al, 2000). In particular, induction of pore formation in the outer membrane of Escherichia coli has been recently ascribed to lysozyme (Derdre et al., 2013). Derdre et al. (2014) established that lysozyme has a high affinity for the LPS monolayer, and is able to insert into the latter as long as polysaccharide moieties are present, causing reorganization of the LPS monolayer. Lysozyme was also shown to be active on the inner membrane, despite 
the lack of evidence for membrane perforation (Derde et al, 2013). There are a number of studies showing that denatured lysozyme (consequently devoid of enzymatic activity) retains antibacterial activity due to membrane perturbation of Gram-positive bacteria and E. coli; these findings are considered to support the hypothesis that disruption of membranes is a second major anti-bacterial mechanism for lysozyme (Ibrahim et al, 1996; Ibrahim et al, 1997; Ibrahim et al, 1998; Derde et al, 2014; During et al., 1999; Ibrahim et al., 2001).

A third mechanism of lysozyme activity against Gram-negative bacteria was suggested by Pellegrini et al., 2000 who provided evidence that lysozyme inhibits DNA and RNA synthesis in E. coli. Finally, the mechanism of lysozyme-mediated autolysin induction proposed by Ibrahim et al. (2001) on Bacillus subtilis has never been described in Gram-negative bacteria. It is also important to note that the contribution of the enzymatic activity of lysozyme to the defence against infections is debatable under the alkaline egg white conditions. Ibrahim et al. (1996) showed an absence of lytic activity for lysozyme at alkaline $\mathrm{pH}$. Considering that the $\mathrm{pH}$ value of egg white reaches 9 a few days after laying, lysozyme could quickly lose its lytic activity during egg storage or hatching. At high $\mathrm{pH}$, lysozyme is thus enzymatically inactive but remains substantially bactericidal presumably due to membrane disruption (Wang and Shelef, 1991).

To conclude on the specific effect of lysozyme on $S$. Enteritidis, it is likely that this bacterium resists the peptidoglycan lytic activity of lysozyme due to the shielding effect of the outer membrane and the inhibitory effect of the periplasmic lysozyme inhibitor (PliC). However, it remains possible that the membrane disruption mechanisms described above could affect $S$. Enteritidis when exposed to lysozyme under the conditions (e.g. high pH, metal-ion chelation) found within the egg white - a possibility that awaits investigation. 


\subsection{Ovotransferrin}

Ovotransferrin is a glycoprotein of $77.7 \mathrm{kDa}$, consisting of a 686 residue single polypeptide chain, and is widely distributed in physiological fluids. This protein is a member of the transferrin family, an extended family of metal-binding transport proteins with an in vivo preference for iron ( $\mathrm{Wu}$ and Acero-Lopez, 2012). Like all transferrins, ovotransferrin is composed of two homologous lobes named the amino-terminal lobe (N-lobe), and the carboxyl-terminal lobe (C-lobe), respectively. Each lobe has the ability to bind one $\mathrm{Fe}^{3+}$ atom with extremely high affinity ( $\mathrm{K}_{\mathrm{a}}$ around $10^{20} \mathrm{M}^{-1}$ Bou Abdallah and El Hage Chahine 1999). Ovotransferrin can also chelate multivalent ions such as zinc, copper and manganese (Ibrahim et al., 2007). Considering the low concentration of iron (around $25 \mu \mathrm{mol} . \mathrm{L}^{-1}$ ) and the high concentration of ovotransferrin $\left(1.7 \mathrm{mmol} . \mathrm{L}^{-1}\right)$ in egg white, it can be concluded that ovotransferrin is predominantly iron-free under the natural conditions of egg white and that all the iron present in egg white is bound to ovotransferrin (Thapon et al., 1994). Thus, ironbinding capacity of ovotransferrin is one of the mechanisms involved in its antibacterial activity since this leads to an iron-deficient environment which is deleterious for bacterial growth. This conclusion is supported by experiments in which the bacteriostatic action of egg albumen against Gram-negative bacteria is shown to fall drastically when iron is added in amounts sufficient for ovotransferrin saturation (Lock and Board, 1992). Furthermore, some studies suggest that the predominant role in preventing growth of Gram-negative bacteria in egg white is performed by ovotransferrin and iron deficiency (Garibaldi et al., 1970, Baron et al., 1997).

Iron participates in many major biological processes and is an absolute necessity for life of all organisms, including almost all bacteria. Thus, many bacteria possess specific strategies to counter the iron restriction conditions encountered in biological fluids such as egg white. 
These include the use of intracellular iron reserves for growth when external iron supplies are restricted. In addition, many bacteria are able to synthetize extracellular ferric chelators, called siderophores (Neilands, 1995), that can efficiently compete with iron-binding proteins (Andrews et al. 2003).

Much research suggests that ovotransferrin has an effect on Gram-negative bacteria independent of iron deprivation. Divalent cations within the outer membrane appear critical for stabilizing the outer membrane through neutralization of the strong negative charges of the lipopolysaccharide molecules. By chelating these membrane-associated cations, metal binding proteins such as ovotransferrin may have an effect on outer membrane integrity (Ellison et al., 1988). As indicated by Valenti (1986), the antimicrobial activity of ovotransferrin could result from a direct interaction between the protein and the bacterial membrane. Aiguilera et al. (2003) also demonstrated the ability of transferrins to permeate the outer membrane of E. coli and to access the inner membrane where they caused permeation of ions in a selective manner. This caused a decrease in the electrochemical potential from -198 to $-56 \mathrm{mV}$, resulting in the uncoupling of the respiration-dependent energy production, leading to bacteriostasis. The bacteriostatic effect of ovotransferrin, i.e. inhibition of growth, is welldocumented but recently Baron et al. (2014) showed a strong bactericidal effect of native ovotransferrin (i.e. decrease in the bacterial population through cell death) on Gram-positive bacteria belonging to the Bacillus cereus group, under the natural alkaline $\mathrm{pH}$ conditions of egg white. Ovotransferrin was shown to provoke a perturbation of the membrane electrochemical potential and membrane dysfunction was strongly suggested to be involved in cell death (Baron et al., 2014). Bactericidal activity of native ovotransferrin has not been reported for Gram negative bacteria.

In conclusion, there is evidence that ovotransferrin possesses distinct mechanisms of bacteriostatic action against Gram-negative bacteria. The first is the well-known iron- 
deprivation effect, which largely explains the bacteriostatic activity of egg white towards Salmonella Enteritidis (Garibaldi, 1970, Baron et al., 1997, Kang et al., 2006). Direct interaction of ovotransferrin with the outer membrane of $S$. Enteritidis is also a possibility, leading to the permeation of the outer layer and consequent bacteriocidal effects.

\subsection{Vitamin chelating proteins}

Egg white contains several vitamin chelating proteins, namely riboflavin-binding protein (binding riboflavin), avidin (binding biotin) and thiamine-binding protein (binding thiamine). By chelating compounds that can be essential for life, these proteins are considered to be part of the defence system of egg white against microorganisms. However, of these three chelating proteins, antibacterial activity has so far only been established for avidin.

Avidin is a cationic homotetrameric glycoprotein present at low concentration $\left(50 \mathrm{mg} . \mathrm{L}^{-1}\right)$ in egg white. This protein has a very high affinity for biotin. The avidin-biotin association is the strongest known non-covalent association to date between a protein and a ligand with a dissociation constant of $6.10^{-16} \mathrm{M}$ (Green, 1990). The avidin-biotin complex is very stable and can withstand short exposures to $132^{\circ} \mathrm{C}$ (Donovan and Ross, 1973). By depriving bacteria of biotin, avidin may exert a bacteriostatic effect (Banks et al., 1986). Biotin is used as a coenzyme for biotin-dependent carboxylases that catalyze the transfer of carboxylate groups. In E. coli, a single biotin-dependent carboxylase is known, the acetyl-CoA carboxylase EC 6.4.1.2 (ACC) (Beckett, 2007). This enzyme catalyzes the binding of bicarbonate and acetylCoA to form malonyl-CoA, which is the first step in the synthesis of fatty acids (Streit and Entcheva, 2003). In addition to this metabolic role, it was recently established that biotin affects cellular transcription (Beckett, 2007). However, some bacteria such as E. coli, S. Typhimurium and B. subtilis are able to synthesize biotin when needed (Beckett, 2007), 
thereby limiting the biotin-deprivation activity of avidin. Independently of this mechanism, avidin might also act by direct interaction with bacteria (Korpela et al, 1984).

\subsection{Protease inhibitors}

Proteases are proteolytic enzymes that hydrolyze peptidyl bonds, releasing peptides and free amino acids from proteins. Proteases and their inhibitors, namely the antiproteases, are involved in many biological processes. Protease inhibitors are also thought to limit the proteolytic potential of bacteria. The protease inhibitors identified to date in egg white are cystatin, ovomucoid, ovoinhibitor, and ovostatin.

Ovostatin, also called ovomacroglobulin, is a large homotetrameric protein with four disulfide linked subunits (4 x $195 \mathrm{kDa}$ ). This minor protein of egg white (around 0.5 g.L $\mathrm{L}^{-1}$ ) belongs to the $\alpha 2$-macroglobulin family. It is known to bind and inhibit various proteases from different classes (seryl-, cysteinyl-, metallo- and aspartyl-proteases), but with a better efficiency towards metalloproteases (collagenase, thermolysin, stromelysin) (Réhault, 2007). Ovostatin is an efficient as antimicrobial due to its ability to inhibit proteases produced by pathogenic bacteria (Molla et al, 1987).

Cystatin is a non-glycosylated small protein $(13 \mathrm{kDa})$ containing two disulfide bonds and is present at very low amounts in egg white $\left(0.05\right.$ g.L $\left.\mathrm{L}^{-1}\right)$. This antiprotease mostly targets cysteine proteases, including ficin, papain and cathepsins B, H, L. Bactericidal activity of cystatin has been established towards Salmonella Typhimurium (Nakai 2000) and E. coli (Wesierska et al, 2005).

Ovomucoid is the second most abundant protein in egg white (13\% of egg white proteins). This protein $(28 \mathrm{kDa}, \mathrm{pI}$ of 4.1$)$ is highly glycosylated and contains nine disulfide bonds. The glycosyl groups are composed of both sialyl-oligosaccharides and sulfated oligosaccharides, and they constitute approximately $25 \%$ of the protein weight. Ovomucoid is a member of the 
Kazal family of protease inhibitors, exhibiting a wide spectrum of antiprotease properties, especially anti-trypsin activity (Kato et al, 1987).

Ovoinhibitor is a minor protein of egg white (around $1.5 \mathrm{~g} . \mathrm{L}^{-1}$ ). It is a $48 \mathrm{kDa}$ glycoprotein possessing seven Kazal-like domains and 21 disulfide bonds. Each domain contains an inhibitory site. Ovoinhibitor has been shown to be active against a large spectrum of serine proteases such as trypsin (Strechter et Berger, 1967; Galzie et al. 1996), chymotrypsin and elastase (ScottTomimatsu et al, 1966; feeney, 1971; Gertier and Feinstein, 1971; Vered et al., 1987, 1981).

Although if egg white ovomucoid and ovoinhibitor have anti-protease activity, their involvement in the protection of egg white against bacterial contamination have not yet been demonstrated.

Ovalbumin related protein $\mathrm{X}(\mathrm{OVAX})$ was detected in hen egg white for the first time in 2005 (Guérin-Dubiard et al, 2005). It is a glycosylated heparin-binding protein of $45 \mathrm{kDa}$ belonging to the serpin family, which also includes the major egg-white protein ovalbumin and the ovalbumin-related protein Y. OVAX is estimated to be 100-times less concentrated in egg white than ovalbumin. Serpins are serine protease inhibitors but to date, no proteolytic activity has been experimentally established for ovalbumin and the related proteins OVAX and OVAY. In contrast, despite high sequence identity between OVAX and ovalbumin, an antimicrobial activity of OVAX towards $S$. Enteritidis has been recently shown using radial diffusion assays, whereas ovalbumin exhibits no antibacterial activity (Réhault-Godbert et al, 2013). This specificity of OVAX may be related to the ability of this protein to bind anionic molecules such as the glycosaminoglycan heparin. Indeed, the anti-Salmonella properties of OVAX are inhibited by blocking the heparin-binding site of the protein with heparin. This suggests competition between bacteria and heparin for the antibacterial active site of OVAX. 
A cluster of cationic amino acid residues present at the surface of OVAX is supposed to interact with heparin and take part in the antibacterial mechanism (Réhault-Godbert et al, 2013).

Heparin cofactor II, another protein of the serpin family, is found in egg white (Mann 2007; D'ambrosio et al., 2008). However its antibacterial activity has never been investigated. Two proteins belonging to pancreatic trypsin inhibitor (Kunitz) family are also found in egg white but their activity in egg white remains unknown.

Protease inhibitors have been considered with interest in multiple therapeutic strategies to fight against infections, because many antimicrobial and antiviral activities have been assigned to them. However, the number of studies on these proteins is not as extensive as for lysozyme or ovotransferrin (xx reports on egg-white protease inhibitors 2000-2015 cf yy for lysozyme and ovotransferrin. Consequently, there is not sufficient evidence to conclude on their actual role in the natural defence system of egg white. Several authors agree that the role of protease inhibitors is minor in the antibacterial properties of egg white, especially considering the strong efficiency of ovotransferrin for hindering the development of Gramnegative bacteria (Garibaldi, 1970; Baron et al, 1997).

\subsection{Other proteins and peptides}

Due to the recent development of sensitive analytical tools based on mass spectrometry, it is now possible to detect exhaustively the protein or peptide components of complex biological fluids, even those constituents present at very low concentrations. Over the past few years, such strategies have considerably increased the number of proteins identified in egg white, which now amount to 158 (Mann and Mann, 2011). The functional homologies of some of these proteins to recognized antimicrobial proteins suggest that they could participate to egg 
defence. Most of these proteins are not purified and their unavailability for experimentations makes their antimicrobial activity only putative.

The protein Tenp was revealed for the first time in unfertilized hen egg white in 2006 by Guérin-Dubiard et al. These authors estimated that the Tenp content of egg white could be 0.1 to $0.5 \%$ of total proteins, i.e. twice- to ten-fold higher than the avidin content. No antibacterial activity of this protein has been reported in literature to date. However, a very strong homology exists between the Tenp primary sequence and the BPI2 domain of members of the Bactericidal Permeability Increasing protein / Lipopolysaccharide binding protein (BPI/LBP) family (Guérin-Dubiard et al., 2006). Protein members of this family are able to bind bacterial lipopolysaccharide of the outer membrane of Gram-negative bacteria and can mediate disruption of the outer and inner membrane of bacteria. These events lead to the inhibition of bacterial growth (Elsbach and Weiss, 1998). Tenp may thus act as an antibacterial component, but further investigations (purification, measurement of biological activity) are needed to confirm its predicted function. Two other proteins belonging to the BPI/LBP family are found in egg white, BPIL2 and Similar-to-BPI (Mann, 2007; D'Ambrosio et al., 2008) but further experiments are also needed to investigate their role in egg white defence.

Defensins are cysteine-rich cationic peptides involved in host innate defence in many living species (vertebrates, invertebrates, plants). These small polypeptides (1 to10 kDa) are characterized by conserved cysteine residues involved in disulfide bond formation which render them extremely compact and stable (Sugiarto and Yu, 2004). Most of these molecules possess a broad spectrum of activity against Gram-positive and Gram-negative bacteria, but also against fungi and viruses (Epand et Vogel, 1999). Most defensins function by electrostatically binding to the microbial cell membrane, and, once embedded, by forming 
multimeric pores that allow efflux of essential ions and nutrients (White et al, 1995). The proteomic analysis of hen egg white (Mann 2007) has revealed the presence of two betadefensin-related molecules, the avian $\beta$-defensin 11 (AvBD11) and gallin.

AvBD11 is a $\beta$-defensin containing 12 cysteine residues involved in six disulfide bonds. The AvBD11 collected from the vitelline membrane (but not from egg white) has been shown, by radial diffusion assays, to inhibit the growth of $S$. Enteritidis, S. Typhimurium, E. coli, Listeria monocytogenes and Staphylococcus aureus in rich medium (Hervé-Grépinet et al, 2010). Gallin contains three disulfide bonds. It is a member of the ovodefensins, a sub-family of $\beta$-defensins found in the egg white of different avian species (chicken, turkey, swan, duck). The recombinant form of this peptide has been shown to inhibit E. coli growth in Phosphate Buffered Salt (PBS) (Gong et al, 2010).

Despite a great number of proteins and peptides that have been identified in egg white throughdevelopment the use of powerful analytical tools, the biological functions of most of them still remain to be determined. It appears that iron deficiency due to the chelating effect of ovotransferrin represents the most likely antimicrobial effect towards $S$. Enteritidis demonstrated to date (Garibaldi, 1970; Baron et al., 1997; Kang et al., 2006).

However, egg white probably contains still unknown molecules involved in bactericidal and/or bacteriostatic activities. All the molecules detected in egg white do not necessarily have a biological and / or an antimicrobial role in the egg itself. Some of them could be passively carried from the oviduct epithelium during egg white formation, and would thus represent "co-products of secretion" with no direct role in the egg white. This is why it is necessary to further investigate the biological functions of these molecules and to clarify their antimicrobial activities, if any. On the other hand, considering those molecules with proven antimicrobial activity, it is important to demonstrate their efficiency under the natural 
conditions of egg white. Indeed, many approaches used to test these molecules are based on growth experiments in rich media and/or at neutral $\mathrm{pH}$ rather than their natural setting. For example, the radial diffusion assays aiming at determining the Minimal Inhibitory Concentration (MIC) of ovalbumin related protein X (Réhault-Godbert et al, 2013) and AvBD11(Hervé-Grépinet et al, 2010) were performed in Trypticase Soy Broth (TSB) or in Luria Bertani (LB) broth at $\mathrm{pH}$ 7. Other studies on bacterial survival in presence of gallin (Gong et al, 2010) were carried out in PBS at pH 7. It is important to bear in mind that these antimicrobial activities may differ under egg white conditions due to potential interactions between different egg white molecules and the influence of alkaline $\mathrm{pH}$ and the ionic environment.

Negative as well as positive interactions (synergistic effects) can also occur between egg white molecules. For example, such interactions could occur in egg white, as described for synergistic ovotransferrin and lysozyme antimicrobial activities. By chelating divalent cations associated with the lipopolysaccharide moieties of the outer membrane of Gram-negative bacteria, ovotransferrin could destabilize this membrane and allow lysozyme to reach and hydrolyze the peptidoglycan. This type of cooperation between lysozyme and lactoferrin has already been established for Gram-negative bacteria (Ellison et Giehl 1991; Facon and Skura, 1996).

\section{Influence of physicochemical and environmental conditions}

In addition to the activity of antimicrobial molecules, physicochemical and/or environmental factors are involved in the antimicrobial efficiency of egg white. Of particular relevance is the remarkable, rapid $\mathrm{pH}$ increase seen in the egg white after laying, resulting in an unusual alkaline $\mathrm{pH}$ for a biological medium. Moreover, egg white is characterized by a viscous and heterogeneous structure, as well as deficiencies in several key nutrients necessary for the 
growth of microorganisms. Temperature is another physical factor that has been shown to be crucial for the efficiency of natural egg defence systems.

\subsection{Egg white $\mathrm{pH}$}

Immediately after laying, carbon dioxide is lost through the pores of the eggshell and the egg white $\mathrm{pH}$ value thus dramatically and rapidly increases from 7.6 up to 9.3 in a few days; the higher the temperature of storage, the quicker the $\mathrm{pH}$ increase and the higher the final $\mathrm{pH}$ value (Sauveur, 1988). The increase in $\mathrm{pH}$ value has potential consequences on bacteria and as well as the activity of egg white molecules.

The maintenance of intracellular $\mathrm{pH}$ around its optimum value (7.6-7.8) is essential for many biological functions, particularly for bacterial enzymatic activities and the status of membranes. An alkaline $\mathrm{pH}$ mainly affects the respiratory status of bacterial cells that must preserve the proton motive power and the electrochemical potential across their membranes. To achieve this under high $\mathrm{pH}$, bacteria accelerate the entrance of protons and block their exportation; they also suppress the systems responsible for high energy expenditure, such as those associated with flagella biosynthesis and chemotaxis (Maurer et al., 2005). Thus, Baron (1998) has shown that $S$. Enteritidis lacks flagella at alkaline $\mathrm{pH}$, which may limit its access to nutrients.

The role of alkaline $\mathrm{pH}$ on the antimicrobial activity of egg white against different bacteria and especially Salmonella has been highlighted by several studies: above pH 8.8, bacteriostatic or bactericidal effects are observed, in contrast to $\mathrm{pH} 7.5$ or 8 that allow either slight bacterial growth or cause bacteriostasis (Kang et al, 2006. Messens et al, 2004. Tranter and Board 1984). As far as egg-white proteins are concerned, alkaline $\mathrm{pH}$ would enhance the antimicrobial activity of ovotransferrin by further limiting the ability of bacteria to obtain sufficient iron (Tranter and Board, 1984). Ovotransferrin activity at alkaline $\mathrm{pH}$ is higher than 
at acidic $\mathrm{pH}$, due to an acceleration of iron release under acidic conditions and a slowdown under alkaline conditions (Halbrooks et al. 2005 ; Okamoto et al., 2004). Recently, Levashov et al. (2010) also showed that lysozyme activity increases at alkaline pH, inconsistently with the study of Ibrahim et al. (2001) where alkaline $\mathrm{pH}$ was shown to inhibit the catalytic activity of lysozyme, without change in the other bactericidal activities of the protein. In is interesting to note that high $\mathrm{pH}$ has been found to promote the bacteriocidal effects of some antibacterial peptides indicating that similar effects may be exhibited within egg white, as suggested by Abriouel et al. (1998).

\subsection{Viscosity and heterogeneous structure of egg white}

The rheological behaviour of egg white depends on the shear rate that is applied. At high shear rates (above $3000 \mathrm{~s}^{-1}$ ), the behaviour is Newtonian from 5 to $50^{\circ} \mathrm{C}$, but egg white is rheo-thinning at low shear rates. Thus, viscosity of fresh egg white is around $30 \mathrm{mPa} . \mathrm{s}$ at $5 \mathrm{~s}^{-1}$, i.e. 30-fold higher than water viscosity (Lucisano et al, 1996). Such a high viscosity probably makes the motility of bacteria in egg white difficult, limiting access to nutrients required for bacterial growth. Moreover, egg white viscosity depends on several parameters: age and feed of the hen, time and storage conditions of the egg, and the fraction of egg white, namely thin $v s$ thick egg white. Thus, the viscosity of thick egg white is 40 -fold higher than that of thin egg white (Lang and Rha, 1982). Because thin and thick egg white fractions are specifically distributed inside the shell egg, at least for few days after laying, these different rheological characteristics induce heterogeneity that restricts access of bacteria to nutrients. Moreover, another source of heterogeneity would be that the iron-ovotransferrin complexes are probably not distributed uniformly within egg white (Li-Chan and Nakai Shuryo, 1989).

\subsection{Mineral composition}


Mineral composition of the egg white is also of particular interest. The absence of free iron makes the egg white quite inhospitable for bacterial growth. Egg white also contains divalent cations such as magnesium and calcium with potential negative effects on the efficacy of egg white antibacterial components. Divalent cations are able to bridge lipopolysaccharides on bacterial surfaces, suggesting that they may serve as competitive inhibitors to cationic antimicrobial molecules. Interestingly, $\mathrm{Mg}^{2+}$ and $\mathrm{Ca}^{2+}$ were found to inhibit the potent bactericidal activity of a heat-denatured form of egg white lysozyme (devoid of lytic activity) against $S$. aureus and E. coli K12 (Ibrahim, 1997). However, the effect of divalent cations on native egg white antibacterial proteins remains to be further investigated.

\subsection{Temperature}

At temperatures below $8^{\circ} \mathrm{C}$, the growth of Salmonella appears impossible in egg white (Ruzckova, 1994; Schoeni et al., 1995). Furthermore, a bactericidal effect is observed with the disappearance of the entire population at $4{ }^{\circ} \mathrm{C}$ within a few days (Chen et al. 2005; Schoeni et al. 1995; Lock and Board 1992). The same phenomenon was observed at $10^{\circ} \mathrm{C}$ by Clay and Board (1991) and Chen et al. (2005), while Schoeni et al. (1995) observe a slight growth.

Between $20^{\circ} \mathrm{C}$ and $30^{\circ} \mathrm{C}$, a growth of one to four logarithmic units per $\mathrm{ml}$ is observed, depending on temperature and incubation time (Clay and Board, 1991; Lock and Board (1992); Ruzickova (1994) Schoeni et al. 1995; Humphrey and Whitehead 1993, Baron et al. (1997), Cogan et al. 2001; Duboccage et al., 2001, Chen et al. 2005; Murase et al., 2005).

For temperatures above $37^{\circ} \mathrm{C}$, a bacteriostatic or bactericidal effect is observed, depending on temperature, incubation time, strain and inoculum levels used (Ruzickova, 1994, Bradshaw et al. (1990); Clavijo et al. 2006; Kang et al. 2006; Tranter and Board 1984, Alabdeh et al., 2011). At $42^{\circ} \mathrm{C}$, a bactericidal effect of egg white is reported in all cases. The 
destruction ranges from less than $2 \log \mathrm{CFU} / \mathrm{mL}$ to $3.5 \log \mathrm{CFU} / \mathrm{mL}$ for incubation times between $24 \mathrm{~h}$ and $96 \mathrm{~h}$ (Kang et al., 2006; Guan et al., 2006).

Alabdeh et al (2011), investigating the effect of temperature from $37^{\circ} \mathrm{C}$ to $48^{\circ} \mathrm{C}$ on the survival of $S$. Enteritidis demonstrated that egg white became bactericidal at temperatures higher than $42^{\circ} \mathrm{C}$. At $45^{\circ} \mathrm{C}$ these authors observed a drastic destruction, this phenomenon is not a simple temperature effect because bacteria were able to grow in optimum medium (TSB) at $45^{\circ} \mathrm{C}$.

This suggests that certain antibacterial activities, leading to bacterial death, are enhanced at temperatures above $37^{\circ} \mathrm{C}$.

Even if the factors outlined above are clearly involved in modulating the antibacterial activity of egg white, a comprehensive understanding of the respective roles of each parameter is difficult. Indeed, different studies cannot be easily compared because of variations in bacterial strains, inoculum size, incubation times and eggs age. Moreover, different combinations of inocula, $\mathrm{pH}$ and temperatures further complicate direct comparison between studies. Recently, Alabdeh et al. (2011) carried out a complete factorial design experiment in order to separately investigate the involvement of environmental factors (temperature, $\mathrm{pH}$ ), inoculum size and egg-white protein concentration om the antimicrobial activity of egg white, as well as the putative interactions between these factors. The behaviour of $S$. Enteritidis and E. coli was compared under these experimental conditions. Three different egg-white protein concentrations $(0 \%$ egg-white protein with egg white filtrate; $10 \%$ egg-white protein with egg-white filtrate; and $100 \%$ egg white protein with egg white filtrate), five temperatures (37, 40, 42, 45, and $48^{\circ} \mathrm{C}$ ), two $\mathrm{pH}$ values (7.8 and 9.3) and six inoculum sizes ( 3 to $8 \log$ $\mathrm{CFU} / \mathrm{ml}$ ) were tested. The combination of 180 different conditions, using the same bacterial strain, the same batch of bacterial cells for inoculation, and the same batch of egg white, 
strongly support the following assumptions. Firstly, egg white proteins play a key role in antimicrobial activity and, depending on environmental conditions, especially temperature and $\mathrm{pH}$, either death or maintenance is observed. The bactericidal activity of egg white appears from $42^{\circ} \mathrm{C}$ for $S$. Enteritidis. Thirdly, interaction between temperature and protein concentration has a significant effect: at the highest tested temperatures, proteins are less important for the bactericidal effect. In the absence of egg-white proteins (in egg-white filtrate), the bactericidal activity is delayed but is effective at $45^{\circ} \mathrm{C}$ for $S$. Enteritidis. Finally, bacterial destruction was higher at $\mathrm{pH} 9.3$ than at $\mathrm{pH} 7.8$.

In conclusion, it was assumed that $S$. Enteritidis destruction in egg white is due to stress accumulation: alkaline $\mathrm{pH}$, iron deprivation, activity of antimicrobial compounds, and elevated temperature. Strikingly, some of the conditions determined for bacterial destruction are very close to the natural conditions encountered during egg formation in the hen genital tract $\left(42^{\circ} \mathrm{C}\right)$, and during hatching (temperature around $42^{\circ} \mathrm{C}$ and alkaline $\mathrm{pH}$ ).

These observations highlight the limitation of many previous studies on the antimicrobial activities of egg white components which fail to utilise conditions reflective of those found in the egg white. Among the broad spectrum of antimicrobial molecules identified in egg white, some have been extensively studied because they represent promising leads for the treatment of various diseases or for food preservation. But very few studies (Baron et al., 1997, Alabedeh et al 2011) have focused on the efficiency of these proteins in the egg white itself, taking into account its intrinsic properties (alkaline $\mathrm{pH}$, ionic composition), environmental conditions, and potential interactions and synergy between molecules.

\section{Genes involved in the specific response of $S$. Enteritidis to egg white exposure}


Most studies aimed at elucidating the ability to survive in egg white are carried out with $S$. Enteritidis. As already noted above, the high occurrence of this serovar in foodborne diseases related to the consumption of eggs and egg products can be explained by the enhanced ability of this serovar, over other Salmonella, to survive in egg white (Clavijo et al., 2006 ; Gantois et al., 2008 ; De Vylder et al., 2013). This makes $S$. Enteritidis a good model for studying the response of bacteria to the egg white defence mechanisms.

Such studies have mainly focus on the identification of specific genes that could endow $S$. Enteritidis with resistance during incubation in egg white. The main approaches used to identify such genes are directed mutagenesis ( $\mathrm{Lu}$ et al, 2003. Cogan et al, 2004. Kang et al, 2006), insertional mutagenesis (Clavijo et al, 2006), in vivo expression technology (IVET) (Gantois et al., 2008, 2009), and a microarray-based transposon library screening (Raspoet et al., 2014). The studies based on mutagenesis differ in terms of methods of mutant construction, screening approaches, strains, and conditions of incubation (inoculum size, temperature) but they have enabled identification of a great diversity of functions involved in the survival of $S$. Enteritidis in egg white. The genes identified or suspected to be involved are listed in Table 4. The genes presented are implicated in membrane structure and function, metabolism of nucleic acids and amino acids, motility, synthesis and DNA repair, invasion and pathogenicity. These results suggest different explanations for the response of $S$. Enteritidis to the antimicrobial effects of egg white.

A first hypothesis is that iron deficiency is a key factor in the bactericidal activity of egg white. Indeed, mutants of $S$. Enteritidis deleted for genes of iron acquisition were not viable in egg white at $37^{\circ} \mathrm{C}$. After addition of iron, some of these mutants ( $\triangle \operatorname{ton} B$ and $\left.\triangle f e o A B\right)$ showed similar growth behaviour to that of the wild type, while others $(\triangle e n t F$ and $\Delta e n t F / \triangle f e o A B)$ were able to survive, but their growth was delayed (Kang et al., 2006). 
Another hypothesis concerns the disruption of the cell envelop through for the action of some of the antimicrobial components of egg white. Thus, mutants encoding a regulator of lipid metabolism and modulation of membrane properties (yijC which encodes FabR) are not viable in egg white at $37^{\circ} \mathrm{C}$ (Clavijo et al. , 2006). The main target would be the outer membrane, and more specifically the lipopolysaccharide moieties since mutations of genes related to the structure (waaJ) and stabilization of lipopolysaccharides (cadA and lysC) cause loss of viability of the bacteria in egg white at $37^{\circ} \mathrm{C}$ (Clavijo et al., 2006). Moreover, Gantois et al., 2009 have shown that $r f b H$, a gene involved in lipopolysaccharide biosynthesis, is essential for growth at $20^{\circ} \mathrm{C}$ and for survival at $42^{\circ} \mathrm{C}$, this temperature corresponding to the hen's body temperature. Raspoet et al. (2014), by comparing an initial transposon library (grown for $7 \mathrm{~h}$ at $37^{\circ} \mathrm{C}$ in $\mathrm{LB}$ broth with streptomycin) and an egg white selected transposon library (initial library incubated in egg white at $42^{\circ} \mathrm{C}$ for $24 \mathrm{~h}$ ) identified 23 genes with a potential role in egg white survival at $42^{\circ} \mathrm{C}$. Among these genes, 16 were found to be involved in lipopolysaccharide biosynthesis. Moreover, these authors showed that a rfaI (encoding the enzyme that catalyzes the early step in lipopolysaccharide biosynthesis) mutant was unable to survive in egg white at $42^{\circ} \mathrm{C}$.

Egg white can also act on the cytoplasmic membrane. During colonization of the oviduct and contamination of the forming eggs by $S$. Enteritidis, the induction of bacterial genes involved in membrane stress (uspBA) and in the monitoring of the status of the cytoplasmic membrane ( $h f l K$ ) was shown (Gantois et al., 2008). These genes are also induced after contact with egg white (Raspoet et al., 2011). Moreover, the gene tatA, which is involved in the transport of folded proteins through the cytoplasmic membrane, is also induced (Gantois et al., 2008). The Tat expression appears essential for various aspects of the virulence including growth in ironlimiting conditions and resistance against antimicrobials compounds (Gantois et al., 2008). 
In addition, the induction of a gene (murA) involved in the synthesis of peptidoglycan was observed (using IVET) in $S$. Enteritidis during hen oviduct colonization and in contaminated eggs, suggesting a response to the permeabilization of the peptidoglycan by lysozyme (Gantois et al., 2008).

Raspoet et al., 2014 highlight the role of htrA, encoding a protease/heat shock protein involved in the clearance of misfolded proteins in the periplasm. The authors suggest that exposure to the stressful environment of egg white at $42^{\circ} \mathrm{C}$ under alkaline conditions might cause accumulation of damaged proteins in a htrA deletion mutant: this mutant is not able to survive at $42^{\circ} \mathrm{C}$. Egg white exposure can also effect DNA integrity, since Lu et al. (2003) observed that mutants for DNA repair genes ( $\triangle y a f D$ and $\Delta x t h A)$ are not viable in egg white at $37^{\circ} \mathrm{C}$. These authors suggest that a nuclease activity of egg white might be responsible for damage to bacterial DNA.

The motility of bacteria is also be disturbed in egg white. Cogan et al. (2004) reported that non-motile mutants of $S$. Enteritidis $(\triangle f l i C$ and $\triangle m o t A B)$ are unable to grow in egg white. Gantois et al. (2008) also showed induction of $f l g G$, that encodes a component of flagella, during the colonization of the oviduct and in the contaminated laid eggs. In addition, these authors observed a reduction in the survival of mutants lacking flagella in egg white at the hen's body temperature $\left(42^{\circ} \mathrm{C}\right)$, compared with the wild strain.

Clavijo et al. (2006) showed that mutants in genes involved in the transport of glutamine and proline, known to play a role in osmoprotection, are not viable in egg white at $37^{\circ} \mathrm{C}$. These authors suggest that egg white provides a hyper-osmotic environment. However, osmotic measurements performed recently in our laboratory indicate a value of around $240 \mathrm{mosm} / \mathrm{L}$ for egg white (unpublished data). This value is lower than that of Tryptone Soy Broth (312.5 mosm/L) used as a control and suggests isotonicity between egg white and bacterial 
cytoplasm. Egg white may therefore be well suited for the growth of $S$. Enteritidis in terms of osmotic pressure at least.

\section{Conclusion}

It appears unquestionable that the antibacterial effect of egg white towards $S$. Enteritidis is multicomponent and multifactorial. Egg white is a complex biological fluid that represents a harsh medium for bacteria. It is a harmful solution containing an arsenal of natural antimicrobial molecules that may interact with bacteria in a synergistic fashion. In addition, several physicochemical parameters, such as the natural alkaline $\mathrm{pH}$, the incubation temperature and the ionic environment, might also modulate the activity of egg-white antimicrobial components and increase the overall stress levels impacting upon bacterial physiology. Biochemical and genetic studies have enabled identification of egg-white antimicrobial molecules on the one hand, and of genes essential for the survival of $S$. Enteritidis in egg white on the other. This dual investigative approach has helped understanding of the bacteriostatic influences and the mechanisms of cell death in egg white at temperature above $37^{\circ} \mathrm{C}$. There is a general agreement that iron deficiency and disruption of bacterial membranes are key processes in egg white defences. The studies of Clavijo et al. (2006) and Kang et al., (2006) help confirm that

(i) egg white inhibits bacterial growth through iron chelation by ovotransferrin,

(ii) egg-white components (lysozyme, ovotransferrin or other antimicrobial molecules) interact with the bacterial envelop and form pores in the bacterial cell wall and

(iii) egg white components penetrate into the cell and kill bacteria through yet unidentified mechanisms.

However, published studies are often difficult to compare because of wide variability in experimental conditions and methods. In addition, the methods of mutagenesis do not provide 
a global approach so their remains a need to account for the interactions and cumulative effects of specific physicochemical and biological factors. Studying the global physiological response of $S$. Enteritidis exposed to egg white represents a strong basis for further understanding the complex and highly effective mechanisms of egg white bactericidal activities. 


\section{References}

Abdallah, F.B., Chahine, J.M., 1999. Transferrins, the mechanism of iron release by ovotransferrin. Eur. J. Biochem. 263, 912-920.

Abriouel, H., Valdivia, E., Gálvez, A., Maqueda, M., 1998. Response of Salmonella choleraesuis LT2 spheroplasts and permeabilized cells to the bacteriocin AS-48. Appl. Environ. Microbiol. 64, 4623-4626.

Aguilera, O., Quiros, L.M., Fierro, J.F., 2003. Transferrins selectively cause ion efflux through bacterial and artificial membranes. FEBS Lett. 548, 5-10.

Andrews, S.C., Robinson, A.K., Rodríguez-Quiñones, F., 2003. Bacterial iron homeostasis. FEMS Microbiol. Rev. 27, 215-237.

Banks, J.G., Board, R.G., Sparks, N.H., 1986. Natural antimicrobial systems and their potential in food preservation of the future. Biotechnol. Appl. Biochem. 8, 103-147.

Baron, F., 1998. Etude du comportement de Salmonella Enteridis dans le blanc d'oeuf (Thèse de doctorat). France.

Baron, F., Gautier, M., 1997. Factors Involved in the Inhibition of Growth of Salmonella Enteritidis in Liquid Egg White. Journal of Food Protection® 60, 1318-1323.

Baron, F., Jan, S., 2010. Qualité microbiologique de l'œuf coquille, in: Nau, F., Guérin-Dubiard, C., Baron, F., Thapon, J.-L. (Eds.), Science et technologie de l'oeuf, Sciences et techniques agroalimentaires. Paris, p. 370.

Baron, F., Jan, S., Jeantet, R., 2010. Qualité microbiologique des ovoproduits, in: Nau, F., GuérinDubiard, C., Baron, F., Thapon, J.-L. (Eds.), Science et Technologie de L'oeuf, Sciences et Techniques Agroalimentaires. Paris.

Beckett, D., 2007. Biotin sensing: universal influence of biotin status on transcription. Annu. Rev. Genet. 41, 443-464. doi:10.1146/annurev.genet.41.042007.170450

Bradshaw, J.G., Shah, D.B., Forney, E., Madden, J.M., 1990. Growth of Salmonella enteritidis in yolk of shell eggs from normal and seropositive hens. Journal of Food Protection 53, 10331036.

Callewaert, L., Aertsen, A., Deckers, D., Vanoirbeek, K.G.A., Vanderkelen, L., Van Herreweghe, J.M., Masschalck, B., Nakimbugwe, D., Robben, J., Michiels, C.W., 2008. A new family of lysozyme inhibitors contributing to lysozyme tolerance in gram-negative bacteria. PLoS Pathog. 4, e1000019. doi:10.1371/journal.ppat.1000019

Chen, J., Shallo Thesmar, H., Kerr, W.L., 2005. Outgrowth of Salmonellae and the physical property of albumen and vitelline membrane as influenced by egg storage conditions. J. Food Prot. 68, 2553-2558.

Clavijo, R.I., Loui, C., Andersen, G.L., Riley, L.W., Lu, S., 2006. Identification of Genes Associated with Survival of Salmonella enterica Serovar Enteritidis in Chicken Egg Albumen. Appl Environ Microbiol 72, 1055-1064. doi:10.1128/AEM.72.2.1055-1064.2006

Clay, C.E., Board, R.G., 1991. Growth of Salmonella enteritidis in artificially contaminated hens' shell eggs. Epidemiol. Infect. 106, 271-281.

Cogan, T.A., Domingue, G., 2001. Growth of Salmonella enteritidis in artificially contaminated eggs: the effects of inoculum size and suspending media. International journal of food microbiology 70, 131-41. doi:10.1016/S0168-1605(01)00540-2

Cogan, T.A., Jørgensen, F., Lappin-Scott, H.M., Benson, C.E., Woodward, M.J., Humphrey, T.J., 2004. Flagella and curli fimbriae are important for the growth of Salmonella enterica serovars in hen eggs. Microbiology (Reading, Engl.) 150, 1063-1071.

D’Ambrosio, C., Arena, S., Scaloni, A., Guerrier, L., Boschetti, E., Mendieta, M.E., Citterio, A., Righetti, P.G., 2008. Exploring the chicken egg white proteome with combinatorial peptide ligand libraries. J. Proteome Res. 7, 3461-3474. doi:10.1021/pr800193y 
Deckers, D., Masschalck, B., Aertsen, A., Callewaert, L., Van Tiggelen, C.G.M., Atanassova, M., Michiels, C.W., 2004. Periplasmic lysozyme inhibitor contributes to lysozyme resistance in Escherichia coli. Cell. Mol. Life Sci. 61, 1229-1237. doi:10.1007/s00018-004-4066-3

Derde, M., Guérin-Dubiard, C., Lechevalier, V., Cochet, M.-F., Jan, S., Baron, F., Gautier, M., Vié, V., Nau, F., 2014. Dry-heating of lysozyme increases its activity against Escherichia coli membranes. J. Agric. Food Chem. 62, 1692-1700. doi:10.1021/jf405155p

Derde, M., Lechevalier, V., Guérin-Dubiard, C., Cochet, M.-F., Jan, S., Baron, F., Gautier, M., Vié, V., Nau, F., 2013. Hen egg white lysozyme permeabilizes Escherichia coli outer and inner membranes. J. Agric. Food Chem. 61, 9922-9929. doi:10.1021/jf4029199

De Vylder, J., Raspoet, R., Dewulf, J., Haesebrouck, F., Ducatelle, R., Van Immerseel, F., 2013. Salmonella Enteritidis is superior in egg white survival compared with other Salmonella serotypes. Poult. Sci. 92, 842-845. doi:10.3382/ps.2012-02668

Donovan, J.W., Ross, K.D., 1973. Increase in the stability of avidin to bacteria and to the outer membrane porin of escheria coli. FEMS Microbiologie letter 3-10.

Duboccage, L., Heyndrickx, M., Grijspeerdt, K., Herman, L., 2001. Growth of Salmonella in egg white. Meded Rijksuniv Gent Fak Landbouwkd Toegep Biol Wet 66, 531-534.

Düring, K., Porsch, P., Mahn, A., Brinkmann, O., Gieffers, W., 1999. The non-enzymatic microbicidal activity of lysozymes. FEBS Lett. 449, 93-100.

Ellison, R.T., Giehl, T.J., 1991. Killing of gram-negative bacteria by lactoferrin and lysozyme. J. Clin. Invest. 88, 1080-1091. doi:10.1172/JCI115407

Ellison, R.T., Giehl, T.J., LaForce, F.M., 1988. Damage of the outer membrane of enteric gramnegative bacteria by lactoferrin and transferrin. Infect. Immun. 56, 2774-2781.

Elsbach, P., Weiss, J., 1998. Role of the bactericidal/permeability-increasing protein in host defence. Curr. Opin. Immunol. 10, 45-49.

Epand, R.M., Vogel, H.J., 1999. Diversity of antimicrobial peptides and their mechanisms of action. Biochim. Biophys. Acta 1462, 11-28.

Facon, M.J., Skura, B.J., 1996. Antibacterial activity of lactoferricin, lysozyme and EDTA against Salmonella enteritidis. International Dairy Journal 6, 303-313. doi:10.1016/09586946(95)00004-6

Feeney, R.E., 1971. Comparative Biochemistry of avian egg white ovomucoids and ovoinhibitors, in: Fritz, H., Tscesche, H. (Eds.), . Proteinase Inhibitors. Berlin.

Galzie, Z., Qasim, M.A., Salahuddin, A., 1996. Isolation and characterization of domain I of ovoinhibitor. Biochim. Biophys. Acta 1293, 113-121.

Gantois, I., Ducatelle, R., 2008. Salmonella enterica serovar Enteritidis genes induced during oviduct colonization and egg contamination in laying hens. Applied and environmental microbiology 74, 6616-22. doi:10.1128/AEM.01087-08

Gantois, I., Ducatelle, R., 2009. Mechanisms of egg contamination by Salmonella Enteritidis. FEMS microbiology reviews 33, 718-38. doi:10.1111/j.1574-6976.2008.00161.x

Gantois, I., Ducatelle, R., Pasmans, F., Haesebrouck, F., Van Immerseel, F., 2009. The Salmonella Enteritidis lipopolysaccharide biosynthesis gene $\mathrm{rfbH}$ is required for survival in egg albumen. Zoonoses Public Health 56, 145-149. doi:10.1111/j.1863-2378.2008.01195.x

Garibaldi, J.A., 1970. Role of microbial iron transport compounds in bacterial spoilage of eggs. Appl Microbiol 20, 558-560.

Gast, R.K., Holt, P.S., 2000. Influence of the level and location of contamination on the multiplication of Salmonella enteritidis at different storage temperatures in experimentally inoculated eggs. Poult. Sci. 79, 559-563.

Gertler, A., Feinstein, G., 1971. Inhibition of porcine elastase by turkey ovomucoid and chicken ovoinhibitor. Eur. J. Biochem. 20, 547-552.

Gong, D., Wilson, P.W., Bain, M.M., McDade, K., Kalina, J., Hervé-Grépinet, V., Nys, Y., Dunn, I.C., 2010. Gallin; an antimicrobial peptide member of a new avian defensin family, the 
ovodefensins, has been subject to recent gene duplication. BMC Immunol. 11, 12. doi:10.1186/1471-2172-11-12

Green, N.M., 1990. Avidin and streptavidin. Meth. Enzymol. 184, 51-67.

Guan, J., Grenier, C., 2006. In vitro study of Salmonella enteritidis and Salmonella typhimurium definitive type 104: survival in egg albumen and penetration through the vitelline membrane. Poultry science $85,1678-81$. doi:10.1093/ps/85.9.1678

Guérin-Dubiard, C., Anton, M., Gautron, J., Nys, Y., Nau, F., 2010. Composition de l'œuf, in: Nau, F., Guérin-Dubiard, C., Baron, F., Thapon, J.-L. (Eds.), Science et Technologie de L'oeuf. Paris, pp. 1-89.

Guérin-Dubiard, C., Pasco, M., Hietanen, A., Quiros del Bosque, A., Nau, F., Croguennec, T., 2005. Hen egg white fractionation by ion-exchange chromatography. J Chromatogr A 1090, 58-67.

Guérin-Dubiard, C., Pasco, M., Mollé, D., Désert, C., Croguennec, T., Nau, F., 2006. Proteomic analysis of hen egg white. J. Agric. Food Chem. 54, 3901-3910. doi:10.1021/jf0529969

Gurtler, J.B., Conner, D.E., 2009. Survival and growth of Salmonella Enteritidis in liquid egg products varying by temperature, product composition, and carbon dioxide concentration. Foodborne Pathog. Dis. 6, 561-567. doi:10.1089/fpd.2008.0202

Halbrooks, P.J., Giannetti, A.M., Klein, J.S., Björkman, P.J., Larouche, J.R., Smith, V.C., MacGillivray, R.T.A., Everse, S.J., Mason, A.B., 2005. Composition of pH-sensitive triad in $\mathrm{C}$-lobe of human serum transferrin. Comparison to sequences of ovotransferrin and lactoferrin provides insight into functional differences in iron release. Biochemistry 44, 15451-15460. doi:10.1021/bi0518693

Hervé-Grépinet, V., Réhault-Godbert, S., Labas, V., Magallon, T., Derache, C., Lavergne, M., Gautron, J., Lalmanach, A.-C., Nys, Y., 2010. Purification and characterization of avian betadefensin 11, an antimicrobial peptide of the hen egg. Antimicrob. Agents Chemother. 54, 4401-4409. doi:10.1128/AAC.00204-10

Humphrey, T.J., Whitehead, A., 1993. Egg age and the growth of Salmonella enteritidis PT4 in egg contents. Epidemiol. Infect. 111, 209-219.

Ibrahim, H.R., Higashiguchi, S., Juneja, L.R., Kim, M., Yamamoto, T., 1996. A structural phase of heat-denatured lysozyme with novel antimicrobial action. Journal of Agricultural and Food Chemistry 44, 1416-23.

Ibrahim, H.R., Hoq, M.I., Aoki, T., 2007. Ovotransferrin possesses SOD-like superoxide anion scavenging activity that is promoted by copper and manganese binding. Int. J. Biol. Macromol. 41, 631-640. doi:10.1016/j.ijbiomac.2007.08.005

Ibrahim, H.R., Iwamori, E., Sugimoto, Y., Aoki, T., 1998. Identification of a distinct antibacterial domain within the N-lobe of ovotransferrin. Biochim. Biophys. Acta 1401, 289-303.

Ibrahim, H.R., Thomas, U., Pellegrini, A., 2001. A helix-loop-helix peptide at the upper lip of the active site cleft of lysozyme confers potent antimicrobial activity with membrane permeabilization action. J. Biol. Chem. 276, 43767-43774. doi:10.1074/jbc.M106317200

Kang, H., Loui, C., Clavijo, R.I., Riley, L.W., Lu, S., 2006. Survival characteristics of Salmonella enterica serovar Enteritidis in chicken egg albumen. Epidemiol. Infect. 134, 967-976. doi:10.1017/S0950268806006054

Kato, I., Schrode, J., Kohr, W.J., Laskowski, M., 1987. Chicken ovomucoid: determination of its amino acid sequence, determination of the trypsin reactive site, and preparation of all three of its domains. Biochemistry 26, 193-201.

Lang, E.R., Rha, C., 1982. Apparent shear viscosity of native egg white. International Journal of Food Science \& Technology 17, 595-606. doi:10.1111/j.1365-2621.1982.tb00219.x

Levashov, P.A., Sedov, S.A., Shipovskov, S., 2010. Quantitative turbidimetric assay of enzymatic gram-negative bacteria lysis. Analytical chemistry 82, 2161-3. doi:10.1021/ac902978u 
Li-Chan, E., Nakai, S., 1989. Biochemical basis for the properties of egg white. Critical reviews in poultry biology (USA).

Lock, J.L., Dolman, J., Board, R.G., 1992. Observations on the mode of bacterial infection of hens' eggs. FEMS Microbiol. Lett. 100, 71-73.

Lucisano, M., Hidalgo, A., Comelli, E.M., Rossi, M., 1996. Evolution of Chemical and Physical Albumen Characteristics during the Storage of Shell Eggs. J. Agric. Food Chem. 44, 12351240. doi:10.1021/jf950485o

Lu, S., Killoran, P.B., Riley, L.W., 2003. Association of Salmonella enterica serovar enteritidis yafD with resistance to chicken egg albumen. Infect. Immun. 71, 6734-6741.

Mann, K., 2007. The chicken egg white proteome. Proteomics 7, 3558-3568. doi:10.1002/pmic.200700397

Mann, K., Mann, M., 2011. In-depth analysis of the chicken egg white proteome using an LTQ Orbitrap Velos. Proteome Sci 9, 7. doi:10.1186/1477-5956-9-7

Masschalck, B., Michiels, C.W., 2003. Antimicrobial properties of lysozyme in relation to foodborne vegetative bacteria. Crit. Rev. Microbiol. 29, 191-214. doi:10.1080/713610448

Maurer, L.M., Yohannes, E., Bondurant, S.S., Radmacher, M., Slonczewski, J.L., 2005. pH regulates genes for flagellar motility, catabolism, and oxidative stress in Escherichia coli $\mathrm{K}$ 12. J. Bacteriol. 187, 304-319. doi:10.1128/JB.187.1.304-319.2005

Messens, W., Duboccage, L., Grijspeerdt, K., Heyndrickx, M., Herman, L., 2004. Growth of Salmonella serovars in hens' egg albumen as affected by storage prior to inoculation. Food Microbiology 21, 25-32. doi:10.1016/S0740-0020(03)00045-5

Molla, A., Matsumura, Y., Yamamoto, T., Okamura, R., Maeda, H., 1987. Pathogenic capacity of proteases from Serratia marcescens and Pseudomonas aeruginosa and their suppression by chicken egg white ovomacroglobulin. Infect Immun 55, 2509-2517.

Murase, T., Holt, P.S., Gast, R.K., 2005. Growth of Salmonella enterica serovar Enteritidis in albumen and yolk contents of eggs inoculated with this organism onto the vitelline membrane. J. Food Prot. 68, 718-721.

Nakai, S., 2000. Molecular Modifications of egg proteins for functional improvement, in: Sim, J.S., Guenter, W. (Eds.), Egg Nutrition and Biotechnology. Oxon, pp. 205-217.

Nikaido, H., 2003. Molecular Basis of Bacterial Outer Membrane Permeability Revisited. Microbiol. Mol. Biol. Rev.67, 593-656.

Neilands, J.B., 1995. Siderophores: structure and function of microbial iron transport compounds. J. Biol. Chem. 270, 26723-26726.

Nys, Y., Sauveur, B., 2004. Valeur nutritionnelle des oeufs. INRA productions animales 385-393.

Okamoto, I., Mizutani, K., Hirose, M., 2004. Iron-binding process in the amino- and carboxylterminal lobes of ovotransferrin: quantitative studies utilizing single Fe3+-binding mutants. Biochemistry 43, 11118-11125. doi:10.1021/bi049147j

Pellegrini, A., Thomas, U., von Fellenberg, R., Wild, P., 1992. Bactericidal activities of lysozyme and aprotinin against gram-negative and gram-positive bacteria related to their basic character. J. Appl. Bacteriol. 72, 180-187.

Pellegrini, A., Thomas, U., Wild, P., Schraner, E., von Fellenberg, R., 2000. Effect of lysozyme or modified lysozyme fragments on DNA and RNA synthesis and membrane permeability of Escherichia coli. Microbiol. Res. 155, 69-77. doi:10.1016/S0944-5013(00)80040-3

Pinto, A.T., Mendonca, A.D., Silva, E.N., 2009. Isolated or associated experimental contamination of albumen and egg yolk for Salmonella Enteritidis and Escherichia coli - influence of temperature and storage time. Arquivo Brasileiro de Medicina Veterinaria e Zootecnia 61, $128-34$. 
Raspoet, R., Gantois, I., Devloo, R., Martel, A., Haesebrouck, F., Pasmans, F., Ducatelle, R., Van Immerseel, F., 2011. Salmonella Enteritidis universal stress protein (usp) gene expression is stimulated by egg white and supports oviduct colonization and egg contamination in laying hens. Vet. Microbiol. 153, 186-190. doi:10.1016/j.vetmic.2011.05.047

Raspoet, R., Shearer, N., Appia-Ayme, C., Haesebrouck, F., Ducatelle, R., Thompson, A., Van Immerseel, F., 2014. A genome-wide screen identifies Salmonella Enteritidis lipopolysaccharide biosynthesis and the HtrA heat shock protein as crucial factors involved in egg white persistence at chicken body temperature. Poult. Sci. 93, 1263-1269. doi:10.3382/ps.2013-03711

Réhault-Godbert, S., Labas, V., Helloin, E., Hervé-Grépinet, V., Slugocki, C., Berges, M., Bourin, M.-C., Brionne, A., Poirier, J.-C., Gautron, J., Coste, F., Nys, Y., 2013. Ovalbumin-related protein $\mathrm{X}$ is a heparin-binding ov-serpin exhibiting antimicrobial activities. J. Biol. Chem. 288, 17285-17295. doi:10.1074/jbc.M113.469759

Réhault, S., Anton, M., Nau, F., Gautron, J., Nys, Y., 2007. Les activités biologiques de l'œuf. INRA productions animales 20, 337-48.

Růzicková, V., 1994. Growth and survival of Salmonella enteritidis in selected egg foods. Vet Med (Praha) 39, 187-195.

Schoeni, J.L., Glass, K.A., McDermott, J.L., Wong, A.C., 1995. Growth and penetration of Salmonella enteritidis, Salmonella heidelberg and Salmonella typhimurium in eggs. Int. J. Food Microbiol. 24, 385-396.

Streit, W.R., Entcheva, P., 2003. Biotin in microbes, the genes involved in its biosynthesis, its biochemical role and perspectives for biotechnological production. Appl. Microbiol. Biotechnol. 61, 21-31. doi:10.1007/s00253-002-1186-2

Thapon, J.-L., Audiot, V., 1994. Composition de l'oeuf de poule, in: Thapon, J.-L., Bourgeois, C.M. (Eds.), L'oeuf et Les Ovoproduits, Tec and Doc. Paris, pp. 6-26.

Tomimatsu, Y., Clary, J.J., Bartulovich, J.J., 1966. Physical characterization of ovoinhibitor, a trypsin and chymotrypsin inhibitor from chicken egg white. Arch. Biochem. Biophys. 115, $536-544$.

Tranter, H.S., Board, R.G., 1984. The influence of incubation temperature and $\mathrm{pH}$ on the antimicrobial properties of hen egg albumen. J. Appl. Bacteriol. 56, 53-61.

Vered, M., Gertler, A., Burstein, Y., 1981. Inhibition of porcine elastase II by chicken ovoinhibitor. Int. J. Pept. Protein Res. 18, 169-179.

Wang, C., Shelef, L.A., 1991. Factors Contributing to Antilisterial Effects of Raw Egg Albumen. Journal of Food Science 56, 1251 - 1254. doi:10.1111/j.1365-2621.1991.tb04745.x

Wesierska, E., Saleh, Y., Trzizka, T., Kopec, W., Siewinski, M., Korzekwa, L., 2005. Antimicrobial activity of chiken egg white chrystatin. World Journal of Microbiology and Biotechnology 59-64.

White, S.H., Wimley, W.C., Selsted, M.E., 1995. Structure, function, and membrane integration of defensins. Curr. Opin. Struct. Biol. 5, 521-527.

Wu, J., Acero-Lopez, A., 2012. Ovotransferrin: Structure, bioactivities, and preparation. Food Research International - FOOD RES INT. doi:10.1016/j.foodres.2011.07.012

Yoshinori Mine, J.K.-N., 2004. Biologically Active Hen Egg Components in Human Health and Disease. Journal of Poultry Science - J POULT SCI 41, 1-29. doi:10.2141/jpsa.41.1 